BRIEF COMMUNICATION

\title{
Leishmania infantum AS A CAUSATIVE AGENT OF CUTANEOUS LEISHMANIASIS IN THE STATE OF MATO GROSSO DO SUL, BRAZIL
}

\author{
Ludiele Souza CASTRO(1), Adriana de Oliveira FRANÇA(1), Eduardo de Castro FERREIRA(2), Günther HANS FILHO(3), Minoru German HIGA JÚNIOR (1),
} Célia Maria Ferreira GONTIJO(4), Agnes Antônia Sampaio PEREIRA(4) \& Maria Elizabeth Moraes C. DORVAL(5)

\begin{abstract}
SUMMARY
Cutaneous leishmaniasis is caused by different species of the Leishmania genus. Leishmania (Leishmania) infantum, causing cutaneous leishmaniasis, has been described in patients living in areas where visceral leishmaniasis is endemic. In this study, it was possible to characterize this species in seven slides from cutaneous tissue imprints from patients with cutaneous leishmaniasis in the State of Mato Grosso do Sul, Brazil.
\end{abstract}

KEYWORDS: Cutaneous leishmaniasis; PCR; Leishmania infantum.

The present study reports a case of Leishmania (Leishmania) infantum as an agent of cutaneous leishmaniasis (CL) in patients from the State of Mato Grosso do Sul (Brazil). This is the first description of $\mathrm{CL}$ in immunocompetent patients in Brazil.

The species $L$. infantum was first associated with CL in France, in $1980^{1}$, where more autochtonous cases have been reported since then ${ }^{1,2,3}$. Since this first retrieval, several cases of CL have been reported in other Mediterranean countries ${ }^{4,5,6,7,8}$. Cutaneous leishmaniasis cases due to L. infantum are mainly reported in areas where the visceral disease is endemic.

In Mato Grosso do Sul (Fig. 1), leishmaniasis is endemic and is a significant threat to public health ${ }^{9,10}$, where 42.9 cases were reported per 100,000 inhabitants from 2010 to 2013 for visceral leishmaniasis (VL), and 21.6 cases per 100,000 inhabitantsfor CL in the same period. Despite the fact that Leishmania (Leishmania) amazonensis and Leishmania (Viannia) braziliensis have been detected in the human population $^{10,11,12}$, studies on the isolation of species that cause CL in the State are scarce.

From 2010 to 2013, 52 slides from cutaneous tissue imprints following punch biopsy, stained by the Giemsa method, with positive diagnosis of CL by direct examination were retrospectively scraped using a sterile scalpel for removal of all the material, which was inserted in a polypropylene tubes of $1.5 \mathrm{ml}$. Then, $600 \mu \mathrm{L}$ of Cell Lysis Solution was added, and this solution was subjected to DNA extraction with

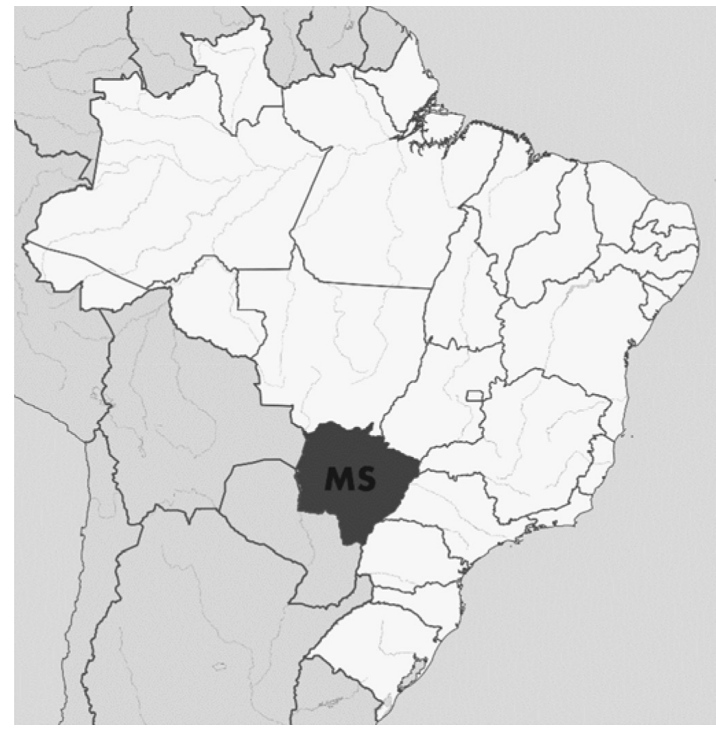

Fig. 1 - The State of Mato Grosso do Sul (MS) in Brazil

a commercial kit (Promega Wizard® Genomic DNA Purification), following the manufacturer's instructions.

The PCR reaction was performed as described by VOLPINI et $a l .{ }^{13}$ and DE ANDRADE et al. ${ }^{14}$. For amplification of the kinetoplast

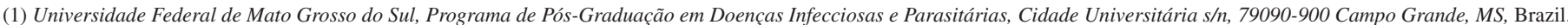

(2) Fundação Oswaldo Cruz /Fiocruz Mato Grosso do Sul, Rua Gabriel Abrão 92, 79081-746 Campo Grande, MS, Brazil.

(3) Universidade Federal de Mato Grosso do Sul, Ambulatório de Dermatologia, Hospital Universitário, Cidade Universitária s/n, $79090-900$ Campo Grande, MS, Brazil.

(4) Fundação Oswaldo Cruz, Laboratório de Leishmanioses, Centro de Pesquisas René Rachou, Av. Augusto de Lima 1715 Bairro Preto, $30190-002$ Belo Horizonte, MG, Brazil.

(5) Universidade Federal de Mato Grosso do Sul, Laboratório de Parasitologia Clínica (LAC), Cidade Universitária s/n, $79090-900$ Campo Grande, MS, Brazil.

Correspondence to: Maria Elizabeth Moraes C. Dorval. E-mail: mecdorval@gmail.com 


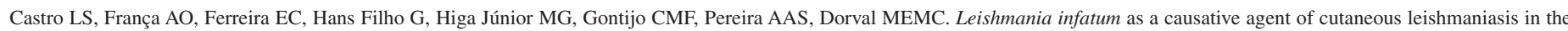
State of Mato Grosso do Sul, Brazil. Rev Inst Med Trop Sao Paulo. 2016;58:23.

DNA of Leishmania sp., the following primers were used: A: 5'$(\mathrm{C} / \mathrm{G})(\mathrm{C} / \mathrm{G})(\mathrm{G} / \mathrm{C}) \mathrm{CC}(\mathrm{C} / \mathrm{A}) \mathrm{CTA}$ T(T/A)TTACACCAACCCC 3' and B: 5'-GGGGAGGGGCGTTCTGCGAA-3'. A fragment of 120 bp was obtained.

Afterwards, 43 samples were considered positive, and subjected to RFLP analysis, where the PCR product was incubated with $10 \mathrm{U}$ of the enzyme Hae III for 4 hours at $37{ }^{\circ} \mathrm{C}^{13}$. In all the reactions, DNA of L. braziliensis (MHOM/BR/75/M2903), L. infantum (MHOM/BR/74/ PP75), L. amazonensis (IFLA/BR/67/PH8), and negative controls were used. The DNA used as a positive control was obtained by washing parasites from a culture mass with PBS and a subsequent DNA extraction. A sample containing the reagents mixture with $5 \mu \mathrm{L}$ of water, without DNA, was used as a negative control.

After the sample analysis, it was possible to characterize the species of Leishmania, in 40 patients, but in three cases the profile generated in RFLP was not conclusive. Thus, Leishmania (Leishmania) infantum was characterized in the lesions of seven patients with CL (17.5\%) (Fig. 2). Of these patients, only one had coinfection with HIV and VL and presented skin lesions. The other patients did not exhibit immunodepression or the associated visceral disease during the diagnosis and therapy.

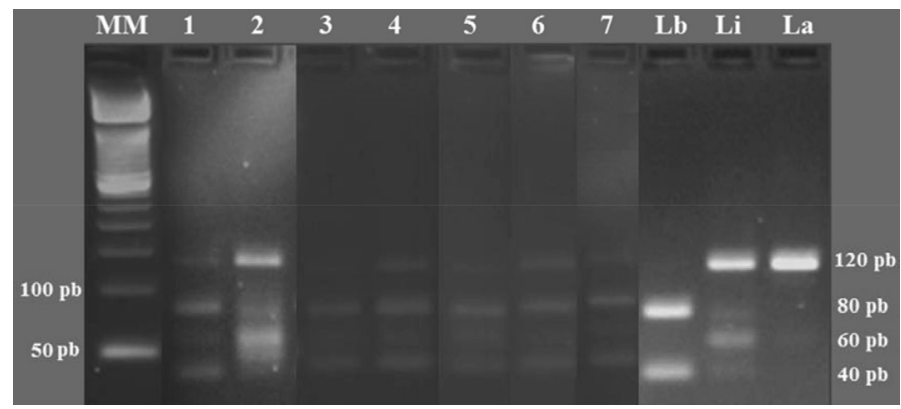

Fig. 2 - RFLP patterns obtained after Hae III digestion of kDNA amplicons. MM - molecular marker - $50 \mathrm{bp}, 1$ to 7 - analyzed samples, Lb - positive control of L. braziliensis, $\mathrm{Li}$ - positive control of L. infantum, La - positive control of L. amazonensis.

Leishmania infantum has been identified as a causative agent of CL in humans from the Mediterranean. In the Southeast of Europe, this is the only species that has been detected in autochthonous cases ${ }^{5}$.

In France, a fairly comprehensive study examined all the cases of leishmaniasis in the country, from 2009 to 2012. At that time, of the 317 autochthonous cases of leishmaniasis, 39 (12.3\%) were cases of CL and all of them due to L. infantum ${ }^{2}$.

Cases of L. infantum as an etiological agent of CL have previously been described in the Americas ${ }^{15,16,17,18}$. In Brazil, this species was first reported in the cutaneous lesions of immunosupressed patients by OLIVEIRA NETO et al. ${ }^{19}$. However, in the State of Mato Grosso do Sul, this species has only been isolated in patients with $\mathrm{VL}^{12,20}$.

The finding of L. infantum in lesions of patients with CL in Mato Grosso do Sul is expected, since there are several reports of the presence of this species causing this clinical manifestation in endemic areas for VL in the Old and New World, as already mentioned. The scarcity of molecular studies aimed at identifying the species involved in cases of
$\mathrm{CL}$ in this area contributed to the fact that $L$. infantum have not been previously identified, so that CL cases for this etiology are probably underdiagnosed and certainly undernotified.

This is the first description of the participation of L. infantum as a causative agent of the disease in immunocompetent patients in Brazil.

The identification of Leishmania spp. in certain transmission foci, particularly in areas where different sympatric species occur is important since it will improve the epidemiological knowledge of this disease. In addition, it contributes to the adoption of control measures, improvement of prognosis, and selection of appropriate therapeutic protocols ${ }^{21,22,23}$.

Besides the characterization of the species, the isoenzyme identification of circulating strains can provide important information about these dermotropics strains, as observed in different locations ${ }^{24,25}$. Further studies are required to isolate and characterize the different strains of Leishmania spp. that affect humans in Mato Grosso do Sul, and to gain a better understanding of their tropism for cutaneous areas.

\section{REFERENCES}

1. Rioux JA, Lanotte G, Maazoun R, Perello R, Pratlong F. Leishmania infantum Nicolle, 1908, agent du bouton d'Orient autochtone. A propos de l'identification biochimique de deus souches isolées dans les Pyrénées-Orientales. CR Seances Acad Sci D. 1980;291:701-3

2. Lachaud L, Dedet JP, Marty P, Faraut F, Buffet P, Gangneux JP, et al. Surveillance of leishmaniases in France, 1999 to 2012. Euro Surveill. 2013;18:20534.

3. Pratlong F, Dedet JP, Marty P, Portús M, Deniau M, Dereure J, et al. Leishmaniahuman immunodeficiency virus coinfection the Mediterranean basin: isoenzymatic characterization of 100 isolates of the Leishmania infantum complex. J Infect Dis. 1995; 172:323-6

4. Aoun K, Bouratbine A. Cutaneous Leishmaniasis in North Africa: a review. Parasite $2014 ; 21: 14$

5. Del Giudice P, Marty P, Lacour JP, Perrin C, Pratlong F, Haas H, et al. Cutaneous leishmaniasis due to Leishmania infantum. Case reports and literature review. Arc Dermatol. 1998;134:193-8.

6. Frank C, Hadziandoniou M, Pratlong F, Garifallou A, Rioux JA. Leishmania tropica and Leishmania infantum responsible for cutaneous leishmaniasis in Greece: sixteen autochthonous cases. Trans R Soc Trop Med Hyg. 1993;87:184-5.

7. Harrat Z, Pratlong F, Belazzoug S, Dereure J, Deniau M, Rioux JA, et al. Leishmania infantum and L major in Algeria. Trans R Soc Trop Med Hyg. 1996;90:625-9.

8. Scott JA, Davidson RN, Grant HR, Felmingham D, Scott GM, Olliaro P, et al. Aminosidine (paromomycin) in the treatment of leishmaniasis imported into the United Kingdom. Trans R Soc Trop Med Hyg. 1992;86:617-9.

9. Menezes Filho JF, Barros RM, Silva AL, Mambelli M, Silva PG. Leishmaniose cutâneo mucosa ou tegumentar americana: revisão da literatura e caso clínico. Odontol Mod. $1986 ; 13: 32-42$.

10. Nunes VL, Dorval ME, Oshiro ET, Noguchi RC, Arão LB, Hans Filho G, et al. Estudo epidemiológico sobre Leishmaniose Tegumentar (LT) no município de Corguinho, Mato Grosso do Sul - estudos na população humana. Rev Soc Bras Med Trop. 1995;28:185-93.

11. Dorval ME, Oshiro ET, Cupolillo E, Castro AC, Alves T. Ocorrência de leishmaniose tegumentar americana no Estado Mato Grosso do Sul associada à infecção por Leishmania (Leishmania) amazonensis. Rev Soc Bras Med Trop. 2006;39:43-6. 


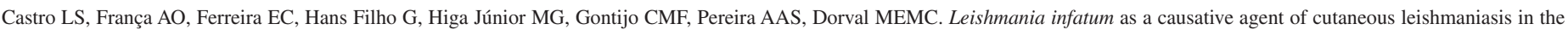
State of Mato Grosso do Sul, Brazil. Rev Inst Med Trop Sao Paulo. 2016;58:23.

12. Lima Júnior MS, Andreotti R, Dorval ME, Oshiro ET, Oliveira AG, Matos MF Identificação de espécies de Leishmania isoladas de casos humanos em Mato Grosso do Sul por meio da reação em cadeia da polimerase. Rev Soc Bras Med Trop. 2009;42:303-8.

13. Volpini AC, Passos VM, Oliveira GC, Romanha AJ. PCR-RFLP to identify Leishmania (Viannia) braziliensis and L. (Leishmania) amazonensis causing American cutaneous leishmaniasis. Acta Trop. 2004;90:31-7.

14. de Andrade HM, Reis AB, dos Santos SL, Volpini AC, Marques MJ, Romanha AJ. Use of PCR-RFLP to identify Leishmania species in naturally-infected dogs. Vet Parasitol. 2006;140:231-8

15. De Lima H, Rodríguez N, Feliciangeli MD, Barrios MA, Sosa A, Agrela I, et al. Cutaneous leishmaniasis due to Leishmania chagasi/Le. infantum in an endemic area of Guarico State, Venezuela. Trans R Soc Trop Med Hyg. 2009;103:721-6.

16. Melby PC, Kreutzer RD, MacMahon-Pratt D, Gam AA, Neva FA. Cutaneous leishmaniais: review of 59 cases seen at the National Institutes of Health. Clin Infect Dis. 1992; 15:924-37

17. Noyes H, Chance M, Ponce C, Ponce E, Maingon R. Leishmania chagasi: genotypically similar parasites from Honduras cause both visceral and cutaneous leishmaniasis in humans. Exp Parasitol. 1997;85:264-73.

18. Zeledón R, Hidalgo H, Víquez A, Urbina A. Atypical cutaneous leishmaniasis in a semiarid region of north-west Costa Rica. Trans R Soc Trop Med Hyg. 1989;83:786.

19. Oliveira Neto MP, Grimaldi G Jr, Momem H, Pacheco RS, Marzochi MC, MacMahonPratt D. Active cutaneous leishmaniasis in Brazil induced by Leishmania donovan chagasi. Mem Inst Oswaldo Cruz. 1986;81:303-9.
20. Oliveira AG, Galati EA, de Oliveira O, de Oliveira GR, Espindola IA, Dorval ME, et al Abundance of Lutzomyia longipalpis (Diptera: Psychodidae: Phlebotominae) and urban transmission of visceral leishmaniasis in Campo Grande, state of Mato Grosso do Sul, Brazil. Mem Inst Oswaldo Cruz. 2006;101:869-74.

21. Bañuls A, Hide M, Prugnolle F. Leishmania and the leishmaniases: a parasite genetic update and advances in taxonomy, epidemiology and pathogenicity in humans. Adv Parasitol. 2007;64:1-109.

22. Jirkù M, Zemanová E, Al-Jawabreh A, Schönian G, Lukes J. Development of a direct species-specific PCR assay for differential diagnosis of Leishmania tropica. Diagn Microbiol Infect Dis. 2006;55:75-9.

23. Wortmann G, Hochberg L, Houng HH, Sweeney C, Zapor M, Aronson N, et al. Rapid identification of Leishmania complexes by a real-time PCR assay. Am J Trop Med Hyg. 2005;73:999-1004.

24. Belhadj S, Pratlong F, Hammami M, Kallel K, Dedet JP, Chaker E. Human cutaneous leishmaniasis due to Leishmania infantum in the Sidi Bourouis focus (Northern Tunisia): epidemiological study and isoenzymatic characterization of the parasites. Acta Trop. 2003; 85:83-6.

25. Martin-Sanchez J, Gramiccia M, Di Muccio T, Ludovisi A, Morillas-Marquez F. Isoenzymatic polymorphism of Leishmania infantum in southern Spain. Trans $\mathrm{R}$ Soc Trop Med Hyg. 2004;98:228-32.

Received: 16 April 2014

Accepted: 10 June 2015 